Original Research Paper

\title{
Geobody Architecture and Petroleum Potential of the Yowi Field, Offshore Eastern Niger Delta, Nigeria
}

\author{
${ }^{1}$ Prince Suka Momta and ${ }^{2}$ Minapuye Isaac Odigi \\ ${ }^{I}$ Department of Geology, University of Port Harcourt, Nigeria \\ ${ }^{2}$ O.B Lulu Briggs Chair, Centre for Petroleum Geosciences, \\ Institute of Petroleum Studies, University of Port Harcourt, Nigeria
}

Article history

Received: 29-01-2015

Revised: 01-07-2015

Accepted: 03-12-2015

\section{Corresponding Author:}

Prince Suka Momta

Department of Geology,

University of Port Harcourt,

Nigeria

Email: princemomta@yahoo.com

\begin{abstract}
A study on geobody architecture and petroleum potential of the Yowi Field has been carried out by integrating well logs and 3D seismic data. The objectives of this study include: The determination of the lateral continuity of key horizons; identification of gross geobody distribution and architecture; and the petroleum potential of the field. Well log correlation shows that key horizons are continuous and laterally extensive across the field. Eleven sand horizons displaying majorly stacked upward-coarsening regressive log profile with high net-to-gross ratio towards the eastern flank of the field have been mapped within $7000 \mathrm{ft}$ thick $(2333 \mathrm{~m})$ interval. A depth structure map generated over the N5.2 sand reveals a structural saddle; an elongate four-way dip closure having two structural culminations. Further analysis using 3D seismic attributes revealed four facies distribution patterns. The Root-Mean-Square (RMS) and Variance attributes were applied to identify subtle lithological variations as indicated by its high and low amplitude anomaly. Four facies depositional patterns recognized from amplitude trends include: Dispersed facies pattern; linear/parallel facies profile; discrete/isolated pattern and meandering configuration. Architectural elements inferred from these amplitude distribution patterns include: Beachbarrier-shoreface depositional profile (about $7077 \mathrm{ft}(2355 \mathrm{~m})$ in length, $1476 \mathrm{ft}(490 \mathrm{~m})$ width on the eastern flank and $783 \mathrm{ft}(260 \mathrm{~m})$ width on the west flank); deep sea channel morphology, chaotic/dispersed turbidite sands and stratigraphic pinchouts. Areas with highest Root-Mean-Square (RMS) amplitude values represent porous and sand-prone prospective units; whereas sections characterized by low amplitude reflections may be interpreted as deposits resulting from pelagic or hemi pelagic sedimentation, or a mud-rich and water-bearing facies. The structural closures form sites for hydrocarbon accumulation in the field. 3D seismic horizon slices remain the best amplitude displays for gross facies identification, selection of optimum drilling locations and for measuring facies architecture.
\end{abstract}

Keywords: Seismic Attributes, Architecture, Petroleum Potential, Barrier Bar, Amplitude

\section{Introduction}

The application of 3D seismic volume attributes to image subsurface geologic features has been in use for more than four decades. They are valuable analytical tools for lithology prediction, identification of various depositional elements, structural analysis and characterization of reservoirs. With the application of different interpretation tools such as horizontal seismic sections (time and horizon slices), computation of seismic attributes, 3D merging of attributes with different colors and the application of neural networks for multi-attribute analysis contribute very effectively for stratigraphic interpretation (Chopra and Marfurt, 2007a; 2007b; 2008a; 2009). In this study we discuss the application of poststack seismic attributes, Root-Mean-Square (RMS) in particular, for detection of stratigraphic features. The RMS amplitude can map directly to hydrocarbon indications in the data and other geologic features which are isolated from background features by amplitude 
response (Hart et al., 2002; Anstey, 2005; Chopra and Marfurt, 2007a; 2007b; 2008a; 2009). It has been used to predict the distribution of geobodies within the YOWI Field and adjacent areas. This family of attribute is derived from amplitude computation and is useful in facies interpretation, stratigraphic mapping and reservoir studies. 3D visualization techniques provide an alternative and interactive means of viewing amplitude and attribute, a volume that facilitate the extraction of meaningful information and improves interpretation accuracy and efficiency (Chopra and Marfurt, 2005; 2008b; Taner, 2001). The application of seismic technology has proffered solution to myriads of subsurface problems due to its high imaging capacity and detection of uncertainties. Using modern computer power and automation certain seismic features give a direct reflection of subtle subsurface stratigraphic elements that are relevant to hydrocarbon entrapment. This is the secret behind most of the discoveries made in recent times in many sedimentary basins across the world.

The aim of this study is to evaluate facies distribution pattern within the study area and adjacent fields using $3 \mathrm{D}$ seismic volume attribute and to establish the lateral continuity of key horizons across the field. This seismic tool is more sensitive to subtle lithological variations and the presence of fluids in porous sedimentary rocks as indicated by high seismic amplitude signal. The volume attribute procedure for achieving the objectives of this study follows a defined petrel workflow that uses established algorithms to output anticipated results. The results obtained will guide exploration and production decisions and give insight into the problem presently encountered in the field.

\section{Geology of the Study Area}

The Yowi Field lies in the offshore depobelt (shallow offshore) in the eastern Niger Delta sedimentary basin. The field and adjacent areas cover an area extent of approximately 229 sq. km. The first well was drilled in the field in 1980 and as at 2010, 49 wells have been drilled in the field. Three lithostratigraphic units of the Niger Delta are well represented in the field with the lowermost Akata Formation occurring at a shallower depth compared to fields within the centre of the Niger Delta sedimentary basin. Two Agbada Members of the eastern Niger Delta, the Qua Iboe Shale and the Biafra sand, occur in the field and they constitute significant stratigraphic elements for hydrocarbon occurrence in the field (Fig. 1). The Benin Formation has a thickness range of 800 to $1200 \mathrm{ft}$, which thins out towards the deep offshore. The Yowi Field structure is a typical rollover anticline associated with an E-W trending growth fault to the North. It exhibits a 4-way closure, rollover anticline containing two structural culminations which are separated by a saddle, the Yowi East and West Flanks. The structure is most apparent within the Agbada formation suggesting synsedimentary development.

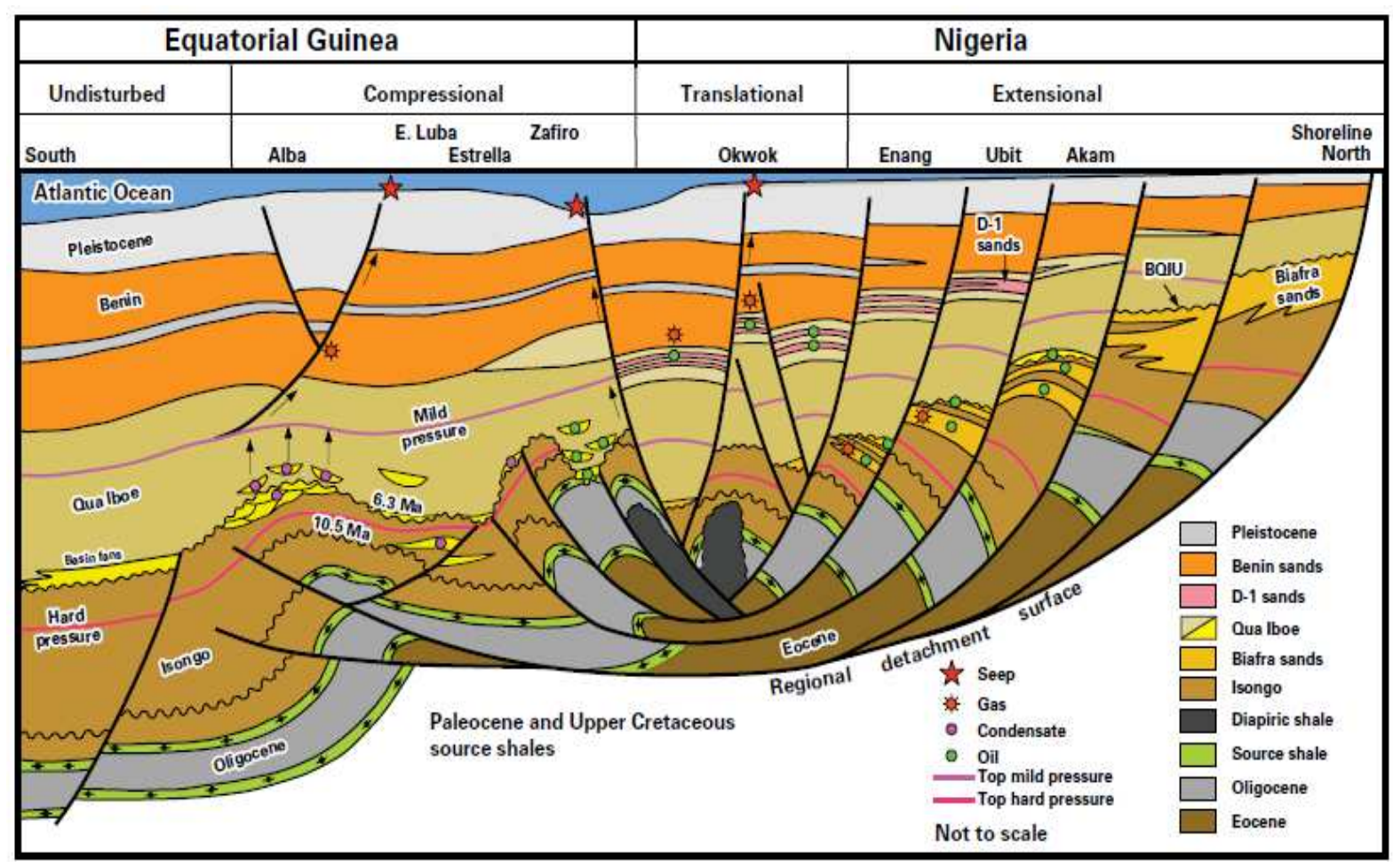

Fig. 1. Play Concept Diagram for Nigeria's Golden Rectangle (Bruso et al., 2004) 
Sedimentation in the eastern Niger Delta is controlled by several factors which include; sediment supply by the Calabar and Benue Rivers, the weathering of the Oban Massif and the Cameroon Mountain and the activity of the active volcanic line of the Cameroon Mountain. In the eastern delta, sedimentation was interrupted by cutting-and-filling events (Burke, 1972; Petters, 1984), resulting in the Agbada, Elekelewu, Soku and Afam channels. During the Pliocene, catastrophic gravity events, possibly related to contemporaneous activity along the Cameroon volcanic line formed the Qua Iboe Channel in the south-eastern offshore area (Reijers, 2011). These erosional features (channels and incised valleys) reported by (Orife and Avbovbo, 1981), are common at the flanks of the Niger Delta.

\section{Methods and Dataset}

The data, 3D seismic volume, was loaded into Petrel database taking the last and the first Inline as well as the $\mathrm{X}$ and $\mathrm{Y}$ coordinates covering the entire survey area. The Seismic Reference Datum, (SRD) is set at zero. The loaded seismic data was realized to make it faster and more convenient to work with. Realization is a process of creating a physical copy of the seismic volume in a Petrel's internal binary. The most widespread evidence for the recognition of a facies type is the seismic amplitude anomaly. The RMS amplitude attribute proved more useful for this analysis. This forms the basis for discrimination between lithology types and the presence of certain fluid within the suspected sand bodies. A correlation panel was generated using five representative wells to establish the lateral continuity of key horizons. The gamma log motif/stacking patterns/trends of five wells guided the mapping of the top and base of key shale units.

\section{Results}

\section{Lateral Continuity of Horizons and Depositional Environments}

The Yowi field is divided into two flanks; east and west, separated by a distance of about 7000 meters. Well log correlation reveals eleven sand bodies from five representative wells, of which four of the sand bodies (N4, N5, N5.2 and N6) have been used to establish the continuity of key horizons across the field (Fig. 2, 3 and 4a). Lithostratigraphic unit is used as the basis for correlation base on gamma ray trends. High gamma ray (with a cut-off of $75^{\circ}$ API value and above) corresponding to the shale base line indicates shale lithology. The top and base of key marker shales form the base and top of suspected sand bodies (Fig. 3). N5.2 reservoir is characterized by clean sands with some silt and shale intercalations. It is bounded at the top and base by distinctive shale units which appear to have a field wide extent. The sands are better developed towards the Yowi East than in the West (Fig. 2 and 3). The Yowi West will have poor reservoir properties towards the top of N5.2 sand, because the gamma ray trend shows a deviation from a more homogeneous blocky shape at the base to a heterogeneous weak fining upward portion of the sand unit (Fig. 4a). The gross thickness of the reservoir ranges from $111 \mathrm{ft}$ to $345 \mathrm{ft}$ with a layer-cake architecture and large lateral extent. Significantly, well correlation helps to: Establish the stratigraphic framework of the reservoirs, build a 3-D petrophysical and dynamic modeling and flow unit demarcation.

The architectural patterns of facies units from well log show more of progradation or regressive sands (Fig. 4) than aggradational and retrogradation. This is common in deltaic sedimentation.

\section{Geobody and Depositional Environments}

The Neogene sediments of the Eastern Niger Delta display distinctive shallow marine and nearshore depositional elements throughout the study area. These are primarily controlled by delta progradation and deposition of sediments within the shoreface and shallow marine realm. Fluvial, wave, longshore currents and tidal processes are the major forces that might have contributed in the systemic distribution and redistribution of sediments in the area. Typical depositional architectures identified based on the stacking patterns include; beach, barrier, shoreface, mouthbar and channels. In most deltaic systems in the world, these depositional systems concentrate huge hydrocarbon deposits (Cook et al., 1999; Sydow et al., 2003; Husmo et al., 2003; Larue and Legarre, 2004; Jackson et al., 2005; 2009; Sech et al., 2009).

\section{Stacking Patterns and Geobody Architecture}

Facies depositional architecture is defined by three major controls. They include; sediment influx, subsidence and sea level changes that provides space for sediment accumulation (accommodation) (Slatt, 2006). Three depositional trends that occur in the study area include; progradation, aggradation and retrogradation (transgression). Each of these events has unique products that aid the reconstruction of their depositional systems. Progradation is the basinward (seaward) migration of facies belts (shoreline), when sediment supply exceeds the rate of creation of accommodation space and results in basinward shift in clinoforms. Progradational patterns form when the rate of deposition exceeds the rate at which accommodation increases. Stacked progradational parasequences have been identified in the Yowi field (Fig. 4a). Repeated progradational patterns (parasequence sets) observed indicate prolonged migration of the shoreline controlled by the larger-scale balance between the rate of sediment supply and accommodation space creation. 


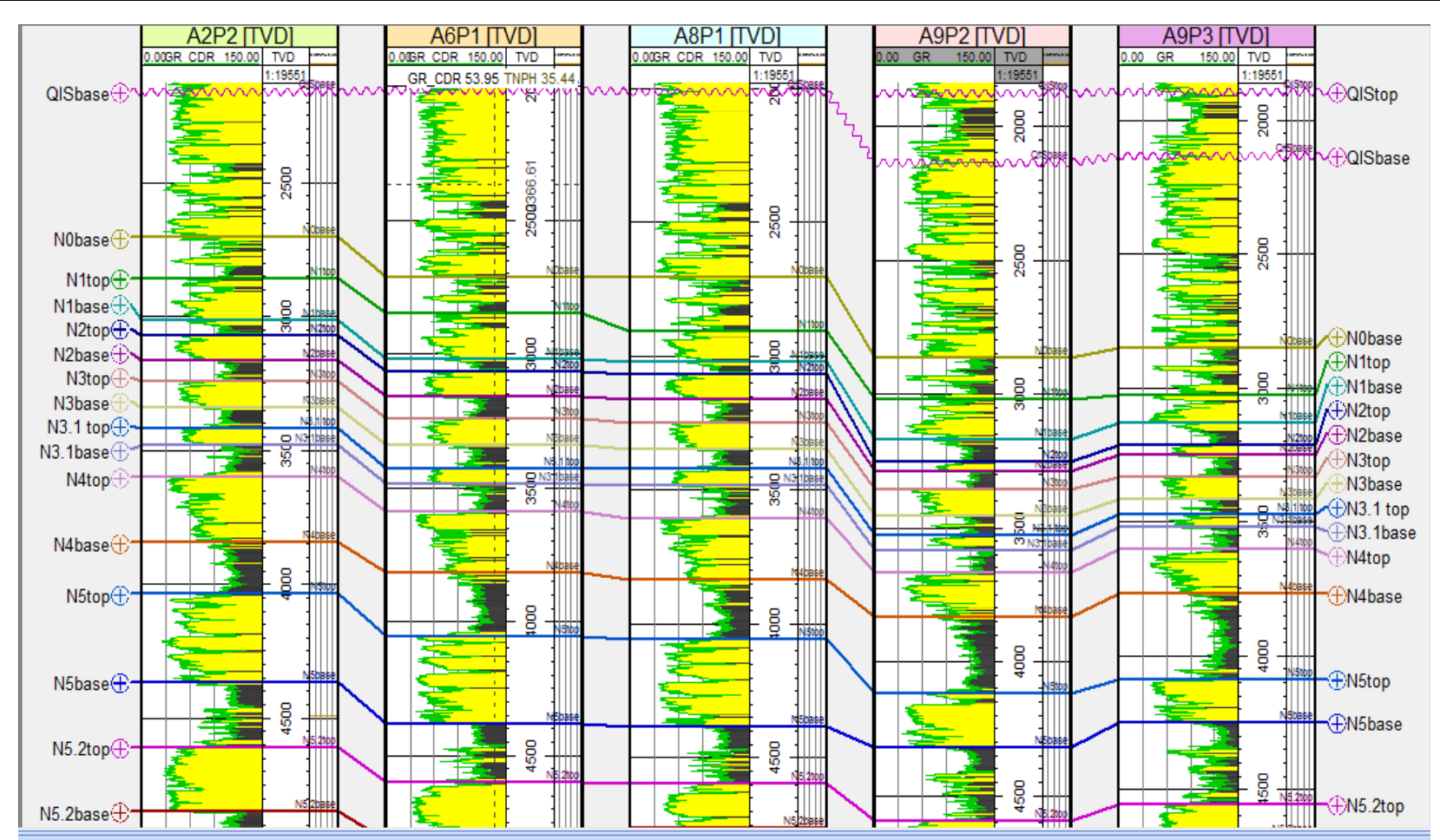

Fig. 2. Litho-correlation of key sand bodies across the field

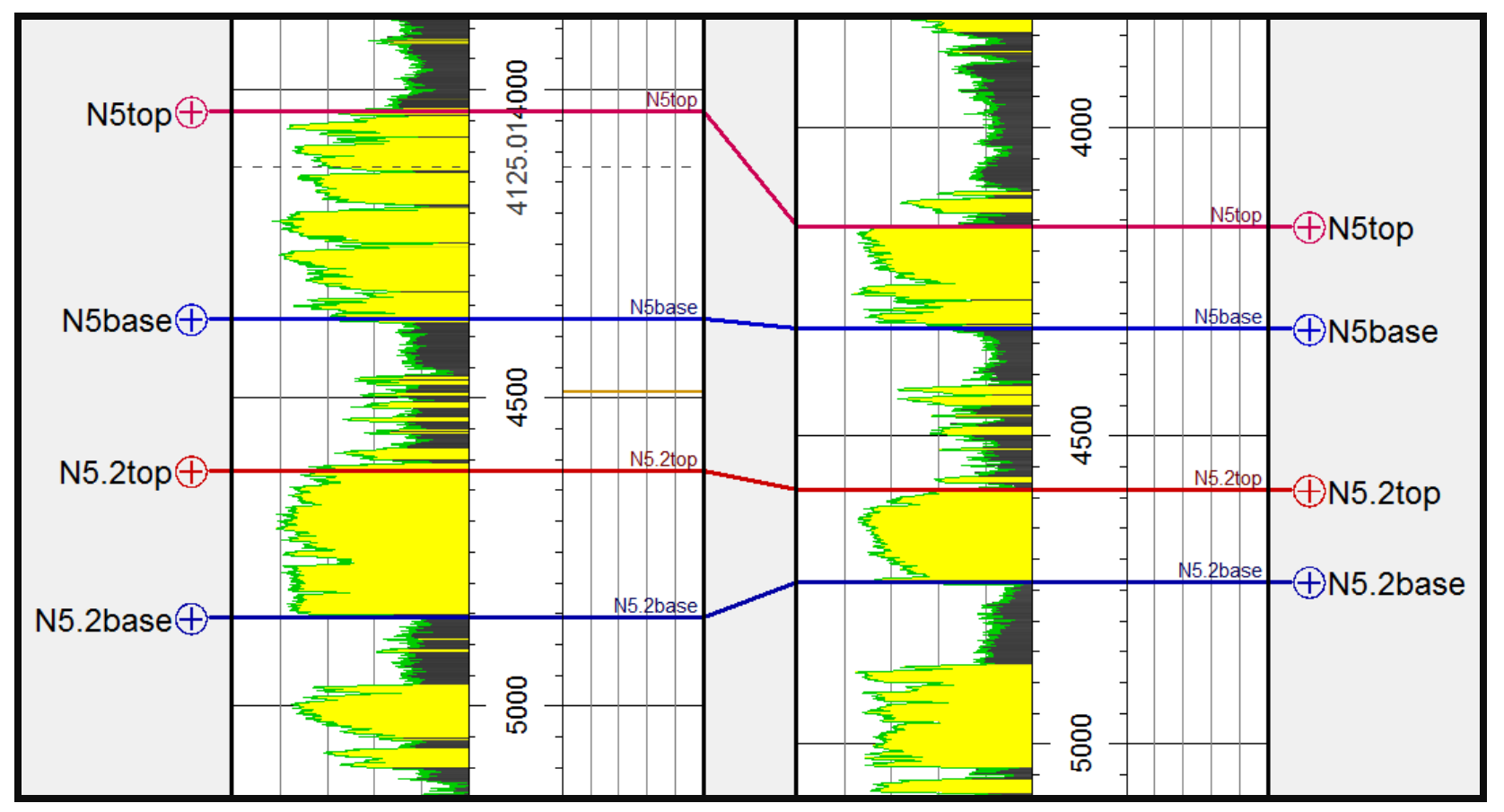

Fig. 3. Key sand units showing log trend and variation in thickness across the field

The architecture generated when the rate of sediment supply is greater than the rate of creation of accommodation space is described in the work of (Howell and Flint, 2005). The stacking pattern is typically of the highstand system tract. Most parasequences in the field are progradational in nature, resulting in an upward-shoaling (upward-coarsening) association of shallow marine lithofacies. 
During the Neogene, there was more sediment supply than available space to accommodate them in the Eastern Niger Delta. An evidence for this event is the regional Base Qua Iboe Shale Unconformity marking the end of Miocene and beginning of Pliocene time and also the presence of stacked producing reservoirs. The delta during this period was at the lowstand (Durogbitan, 2014) when there was serious fluvial incision creating the various channels in the eastern Niger Delta-the Qua Iboe Channel inclusive. There was rapid and repeated increase in water depth as sediments were supplied leading to regular marine flooding isolating the sandstone intervals. This shows a typical progradational parasequence set where each parasequence progrades progressively farther basinward than does the preceding parasequence (Fig. 4a and 4b). The more homogeneous coarsening-upward architecture indicates higher sand development and stronger wave influence sedimentation within the updrift portions of a prograding delta. Inferred depositional elements could be shoreface deposit, mouth bar or tidal bar. Distributary mouthbar deposits are usually reworked by waves and redistributed along the delta front by long-shore currents to form wave-built shoreline features such as beaches, barrier bars and spits.

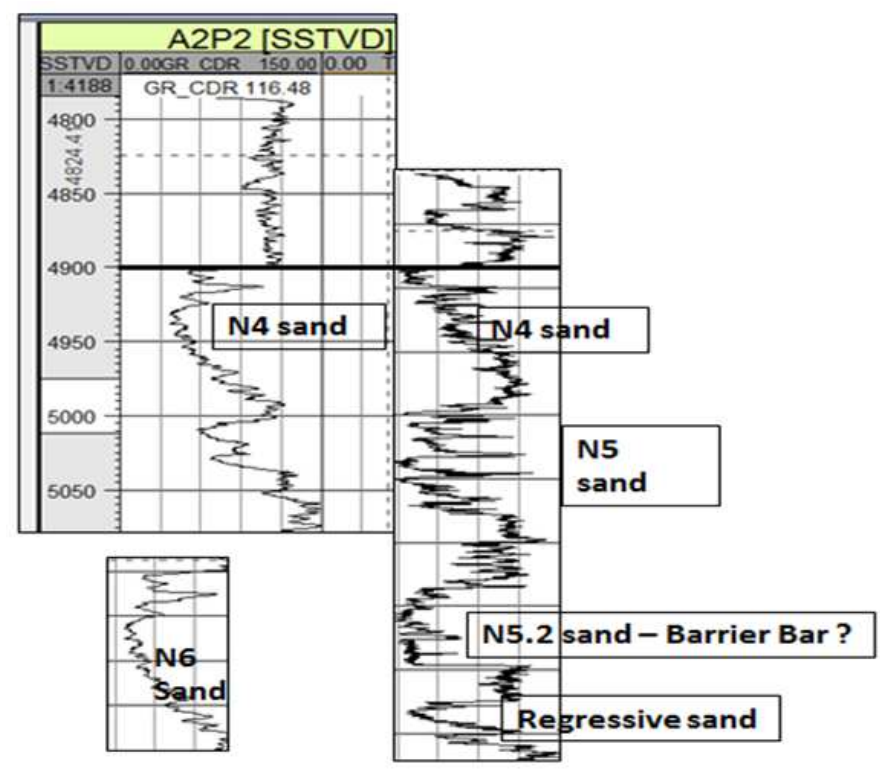

(a)

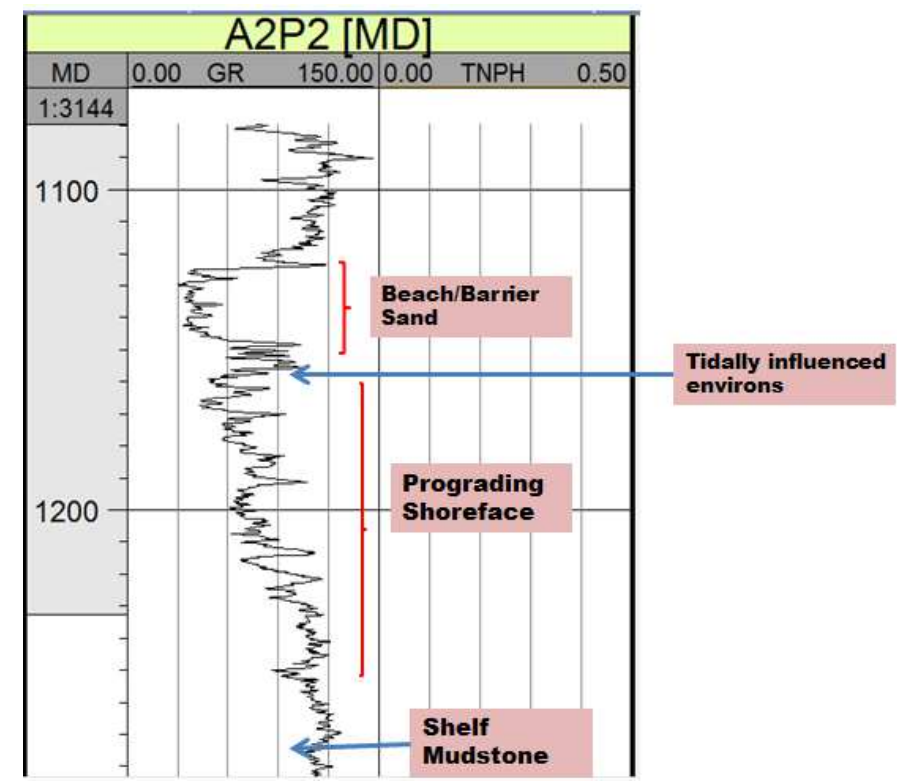

(b)

Fig. 4. (a) Key sand Units Showing log trend and Depositional Environments, (b) Environments associated with Progradation (Beach, Barrier Bar and Shoreface) 
The aggradational pattern develops when sediments stack vertically as a result of a balance between sediment supply and rate of creation of accommodation space. Log facies of this unit has sharp upper and lower contact (blocky) (N5.2 sand in Fig. 4a). The thickness of the boxcar motifs in all the studied intervals is less than $25 \mathrm{~m}$. In the Yowi field, the boxcar gamma-ray log motif reoccurs in all the wells with average thickness of $58 \mathrm{ft}$ in well A2P2 between the intervals of $3357-3412 \mathrm{ft}, 5286-5344 \mathrm{ft}$, $5750-5813 \mathrm{ft}$, 6047-6110ft and 6848-6903ft.). Retrogradation pattern displays a finning upward trend which represents the landward migration of facies belts when the rate of sediment supply is less than the rate at which accommodation space is created. The log characteristic of this unit shows a sharp lower contact with a gradational top (Fig. 2). The bell shape succession usually occurs in three types of environments: Tidal channels, turbidite fills and fluvial or deltaic channels.

\section{Structural Map and Trap Potential of N5.2 Sand}

The N5.2 horizon interpreted on $5 \times 5$ grid cell spacing (Fig. 5a) is good enough to reveal subsurface structures at this level. The interpretation revealed a simple elongated structure trending in an East-West direction, made up of anticlinal growth faults and rollover structure. The structure is separated into two culminations by a saddle (Fig. 5a). Note that all the wells are concentrated on the closures located east and west in the field. An attempt to establish a variation in lithologic response with acoustic impedance using a window of $\pm 25 \mathrm{~ms}$ to extract RMS seismic attribute was conclusive (Fig. 5b). The contour map overlain on the amplitude map shows perfect conformability of amplitude to structure (Fig. 5b). Amplitude extraction analysis serves as a guiding tool for the prediction of hydrocarbon and area of possible sand development. Areas of high amplitude signify locations with hydrocarbon potential and exploration interest (Fig. 5b, 6, 8 and 9).

\section{RMS Amplitude and Geobody Architecture}

Generally, the Root-Mean-Square (RMS) amplitudes are calculated as the square root of the average of the squares of the amplitudes found within an analysis window. Three strong colour variations are indicators of high, medium and low amplitude values: Yellow colour shows the highest amplitude points up to 100 RMS value; the light brown to red intervals are between 50 to 68 , whereas the light green and blue areas have the lowest amplitude values between 0-18 and 20-30 (Fig. 6). These amplitude anomalies may be attributed to constructive or destructive interference caused by two or more closely spaced reflectors and variations in net sand within a sedimentary unit and give information about the energy content of the seismic data used to distinguish between different lithology types. High values of RMS amplitudes reflect a high porosity lithology such as sand that forms our potential hydrocarbon reservoirs. The use of RMS amplitude and other volume attributes are more reliable in geobody prediction and help to guide the proper selection of drillable areas and well placement.

Architectural elements (geobody) interpreted in the study area from seismic attributes include: Dispersed sediment facies (Benin sand), linear/lateral shoreface facies and deep-water mass-transport complexes and channel (Fig. 6). These architectural features reflect a combination of both active deltaic sedimentation and deep marine events. The RMS amplitudes are sensitive to sandstone-bearing depositional systems within the reservoir-bearing successions and help define the spatial distribution of genetically related depositional successions. RMS high amplitude points may represent stratigraphic leads with significant exploration potential in the field.

\section{Dispersed Amplitude Facies}

The entire seismic survey covering the field and adjacent areas is subdivided into three time horizons based on facies distribution patterns: Upper, middle and deep sections. The upper section occurs between 0 to less than $800 \mathrm{msec}$. The middle interval is taken between 800 to $2000 \mathrm{~m} \mathrm{sec}$ and below this interval depicts a deep marine event. The amplitude distribution pattern at the upper time slice shows no distinct orientation of high amplitude event. They are highly dispersed within the section and represents sand-prone facies of continental sediments (the Benin sands) (Fig. 7). The light brownred areas has higher amplitude, whereas the light green and blue areas may be associated with change in lithology or the presence of a particular fluid type.

The figure above shows a combined reflection strength display of the data at time slice 521 milliseconds. The amplitude variation reflects both differences in lithology types and the presence of possible non-hydrocarbon fluid. The dominant colour is the blue which represents areas with lowest amplitude. The anomalously high amplitude areas are dispersed within the section and show majorly grey to brown colours. The yellow colour with highest RMS value is absent within this section, indicating that the facies might possibly be non-hydrocarbon bearing since high RMS amplitude values are commonly related to high porosity lithology, such as sand that may be hydrocarbon-bearing. Section above $800 \mathrm{~m} \mathrm{sec}$ falls within the Benin Formation which is non-hydrocarbon bearing continental sand (Reijers, 2011; Momta and Odigi, 2015). 


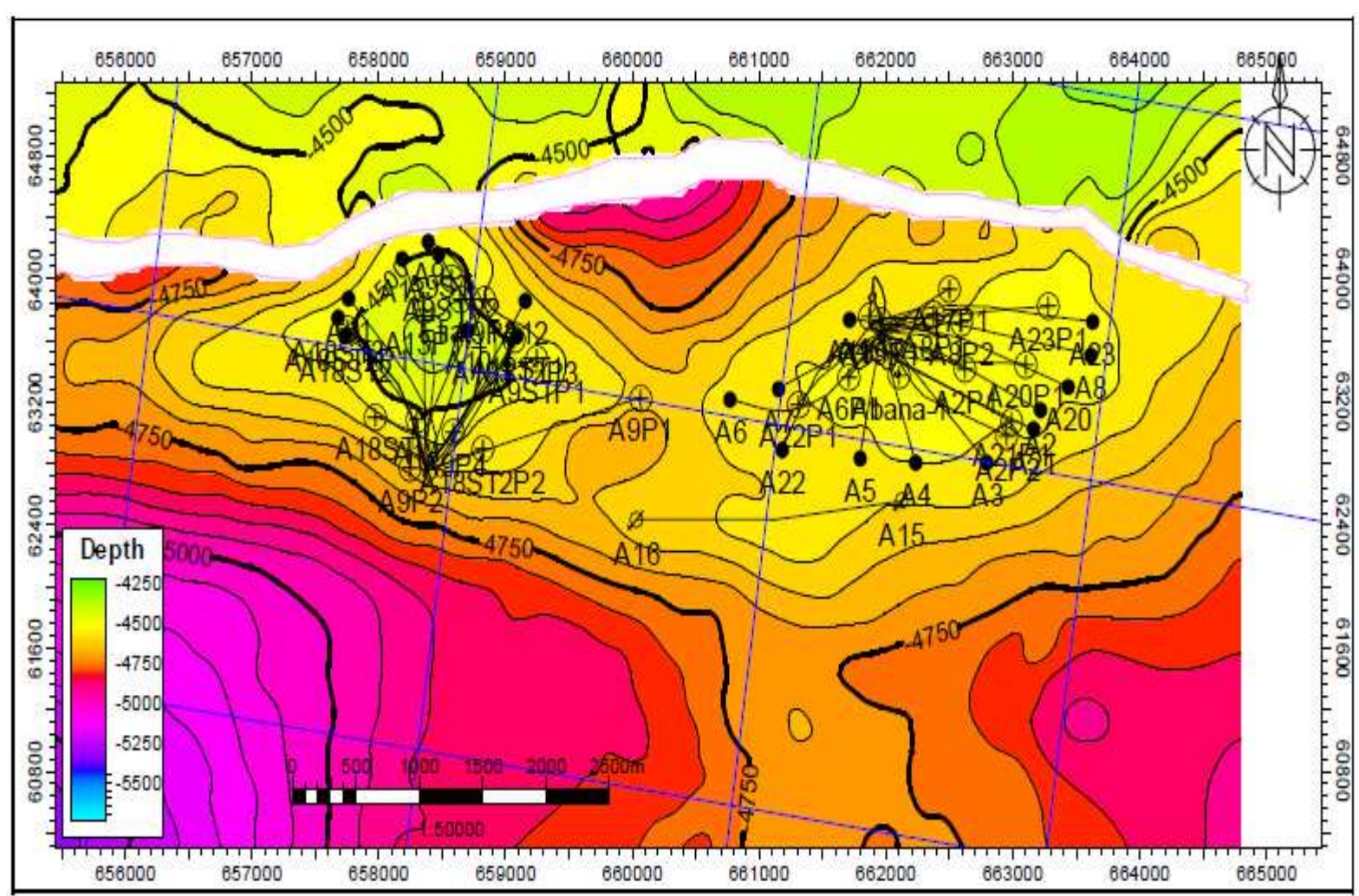

(a)

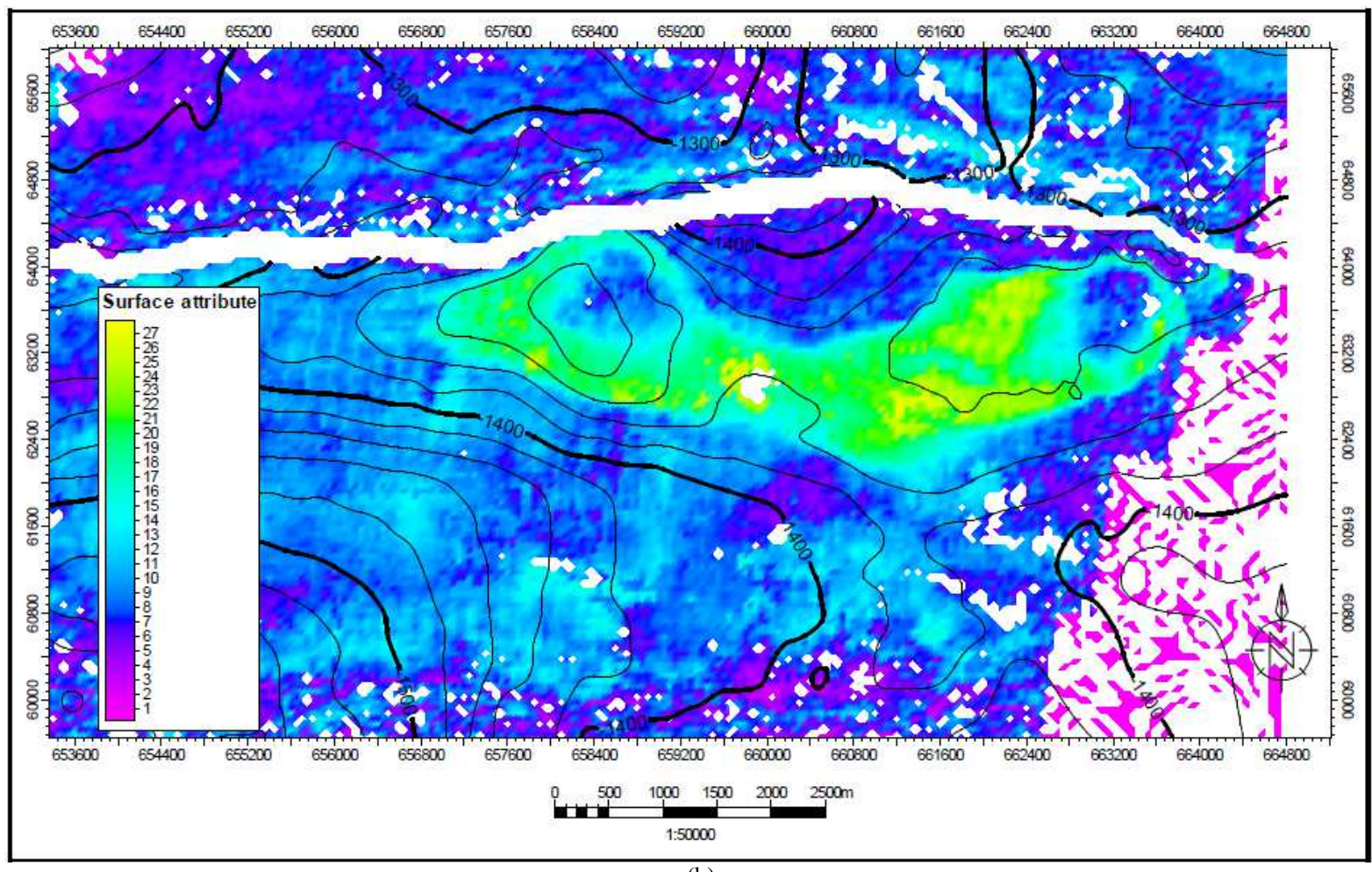

(b)

Fig. 5. (a) Depth Structure Map for N5.2 sand, (b) Root-Mean-Square (RMS) amplitude map overlain on contour map showing conformability of amplitude to structure 


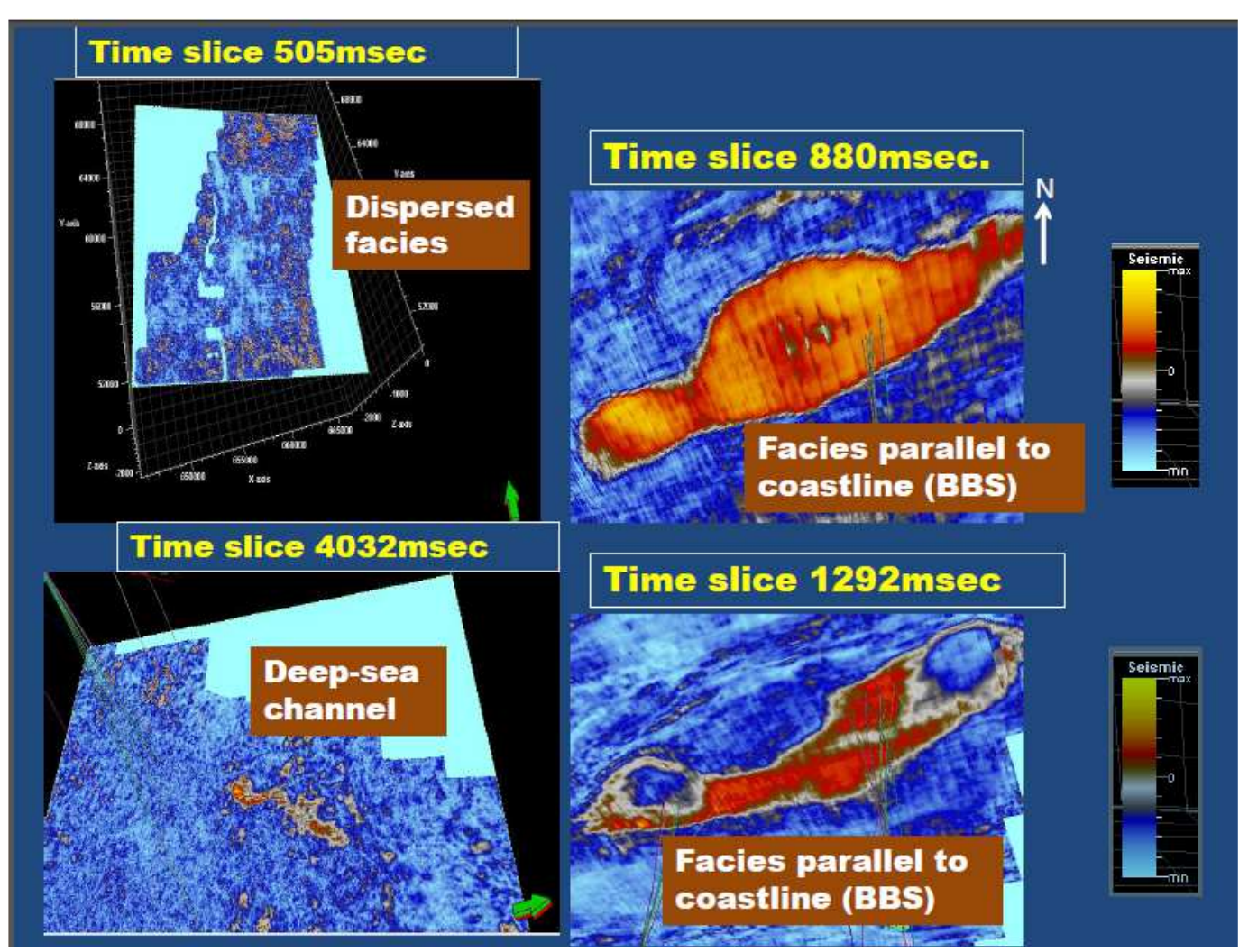

Fig. 6. RMS amplitude for time slice 505, 880, 1292 and 4032 milliseconds

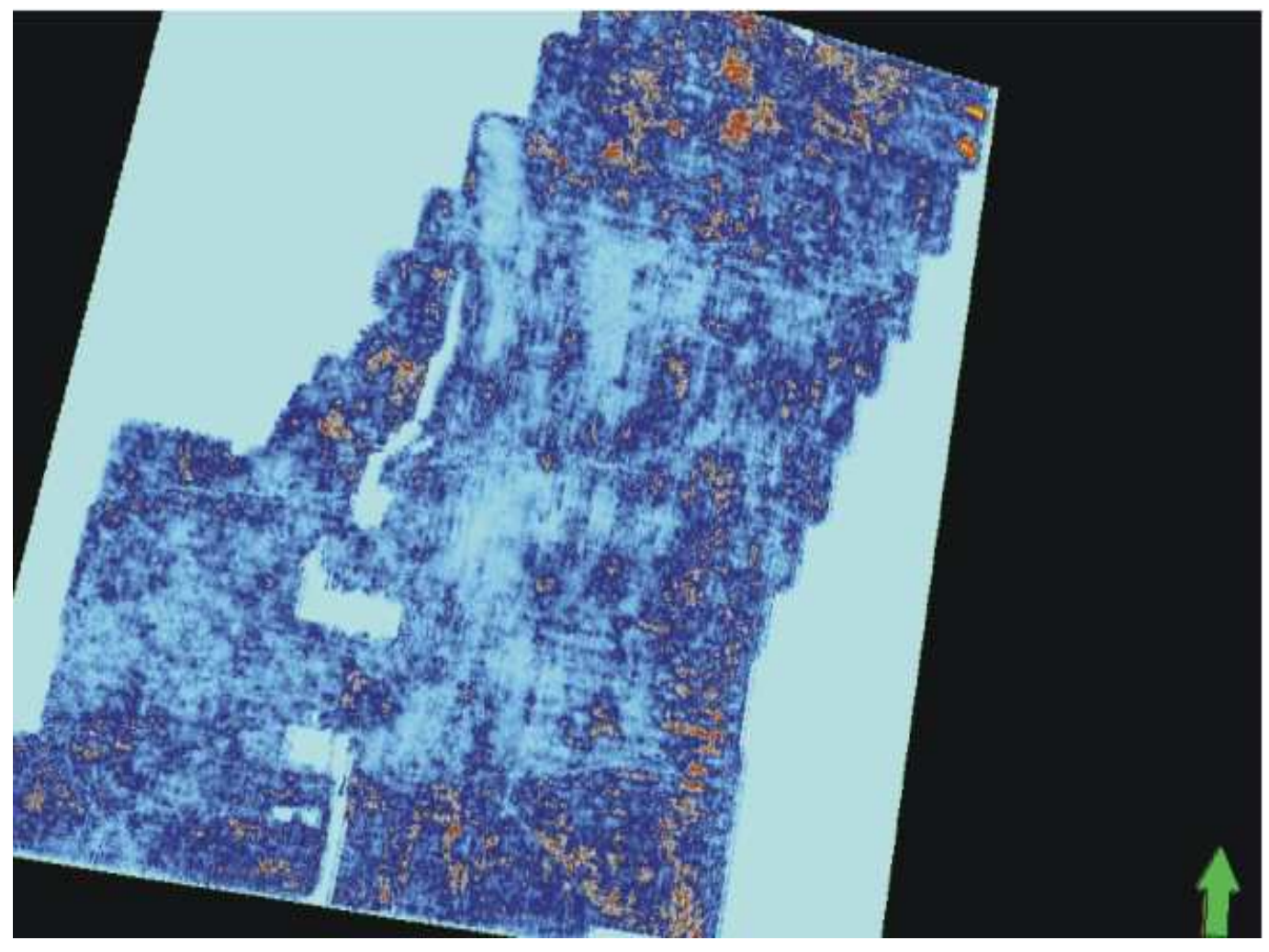

Fig. 7. RMS Amplitude at time $521 \mathrm{~m} \mathrm{sec}$ showing dispersed amplitude pattern 


\section{Laterally Distributed Amplitudes}

This interval occurs between 800 to $1800 \mathrm{~m}$ sec. The seismic character on vertical section displays a continuous reflection pattern which is more obvious on attribute map (Fig. 6). It should be noted that the section above this interval has no defined pattern of amplitude distribution, but here, a well patterned and defined orientation for amplitude events. This suggests a change in depositional setting and processes, from a more fluvially influenced environment and perhaps deltaic plain to a setting affected by a variety of processes which could be a combination of fluvial and marine events. Most of the wells are concentrated on the high amplitude areas (Fig. 8 and 9) suggesting that the area comprises of prospective facies units.

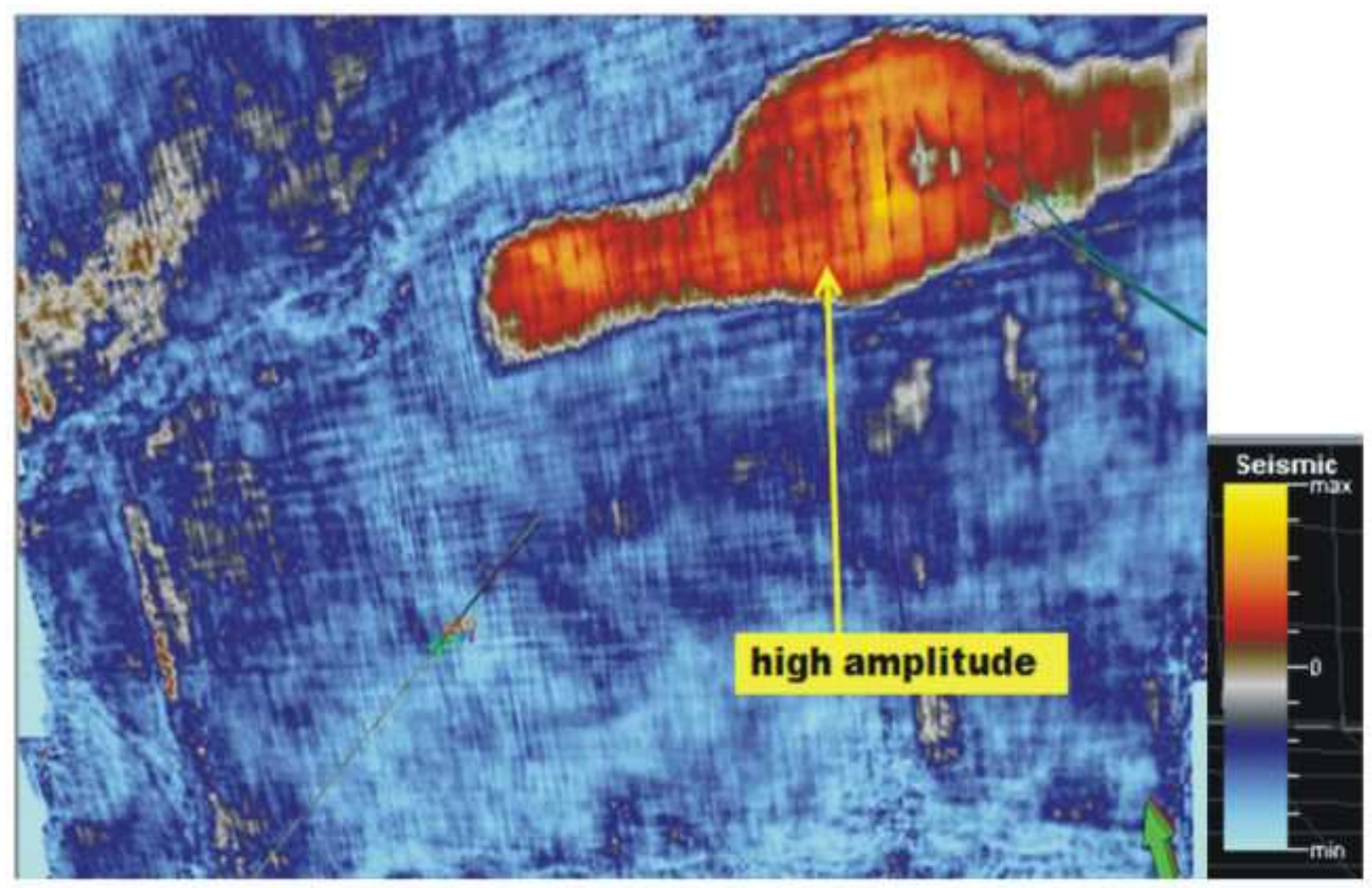

Fig. 8. Time slice at $855 \mathrm{~m} \mathrm{sec}$ showing high amplitude areas penetrated by some wells

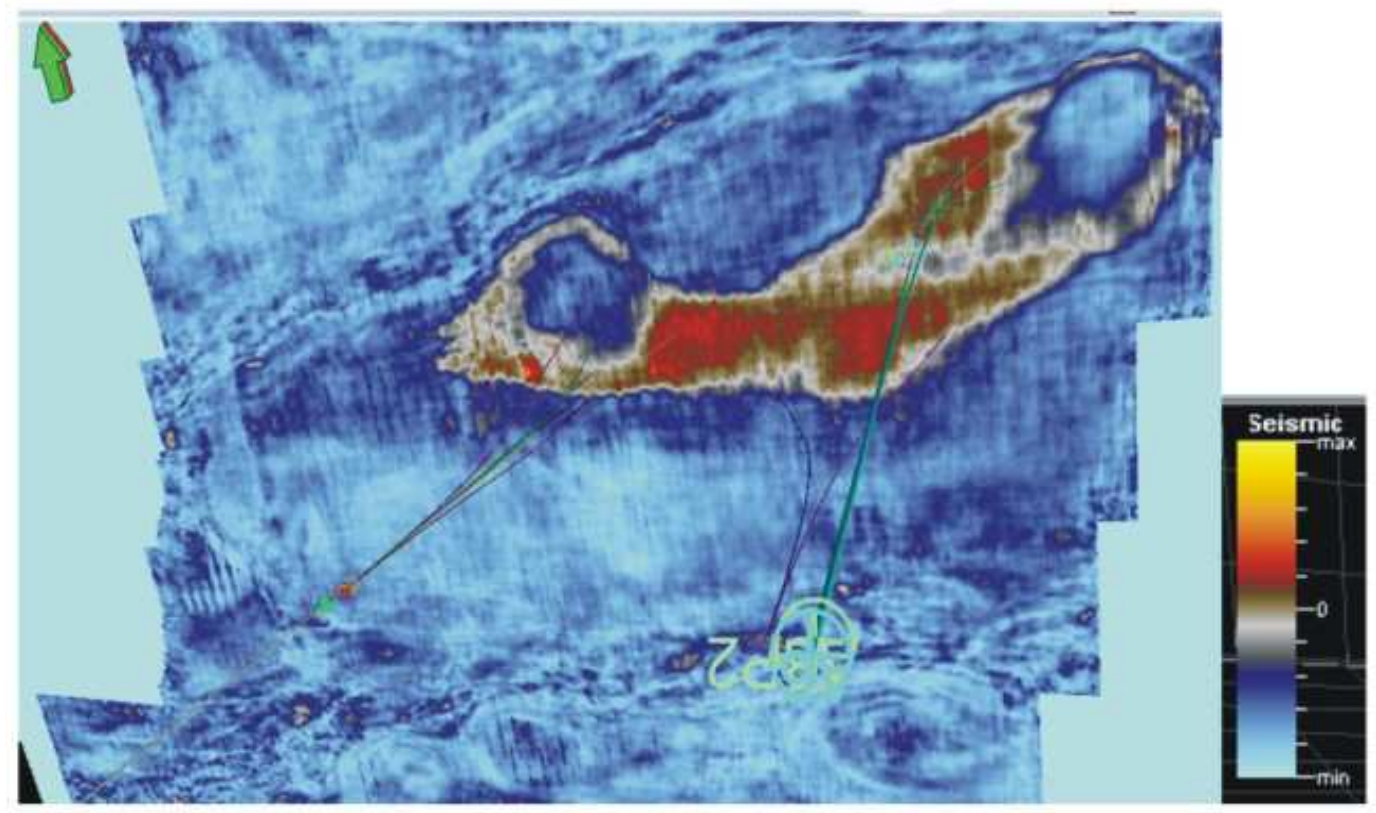

Fig. 9. Time slice at $1293 \mathrm{~m} \mathrm{sec}$ 
The laterally extensive facies here can be inferred to be a shoreface/barrier/beach depositional system which conforms to the well log architectural pattern (Fig. 2, 3 and $4 \mathrm{~b})$. The area shows a greater sediment distribution towards the eastern flank of the field than towards the west. Wells are concentrated within areas with high amplitude reflection. Facies are thicker on the east (1385 m width) than on the western flank $(617 \mathrm{~m})$. The total length of facies from E-W is about $6774 \mathrm{~m}$ (Fig. 9). The shore-parallel geobody represented by high amplitude event in Fig. 8 is penetrated by the wells at $855 \mathrm{~m} \mathrm{sec}$. Some of the wells landed off this geobody at deeper depth between 1200-1400 $\mathrm{m}$ sec (Fig. 10a and 10b) as confirmed by Variance attribute map (Fig. 13). Low amplitude and variance may be due to very low hydrocarbon saturation or the presence of non-hydrocarbon fluid (water) or argillaceous/pelagic sediments. Oil production within this zone can be minimal or totally unproductive.

Most wells landed about $400 \mathrm{~m}$ away from target sand in water-bearing zones (Fig. 10a and 13). This could lead to high water-cut during production, thus, rapid production decline. Also note the linear profile of high amplitude events in adjacent fields north and south of the Yowi Field (Fig. 10a and 10b).

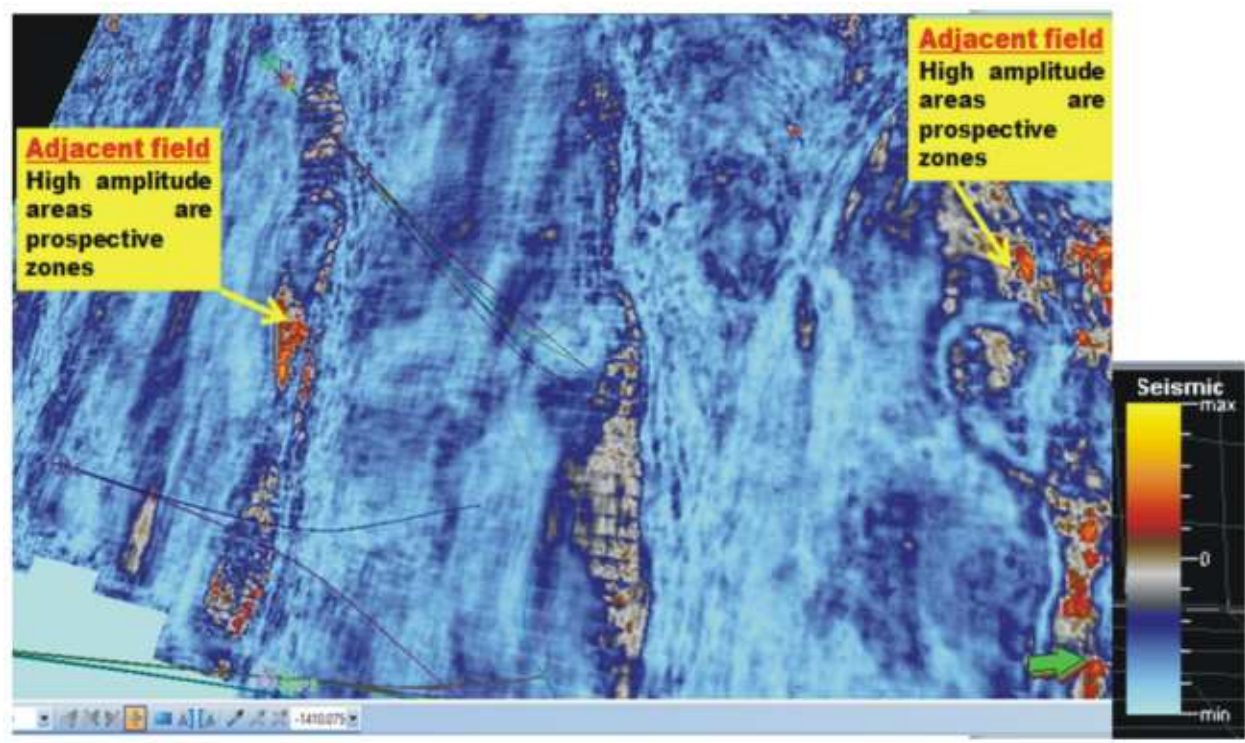

(a)

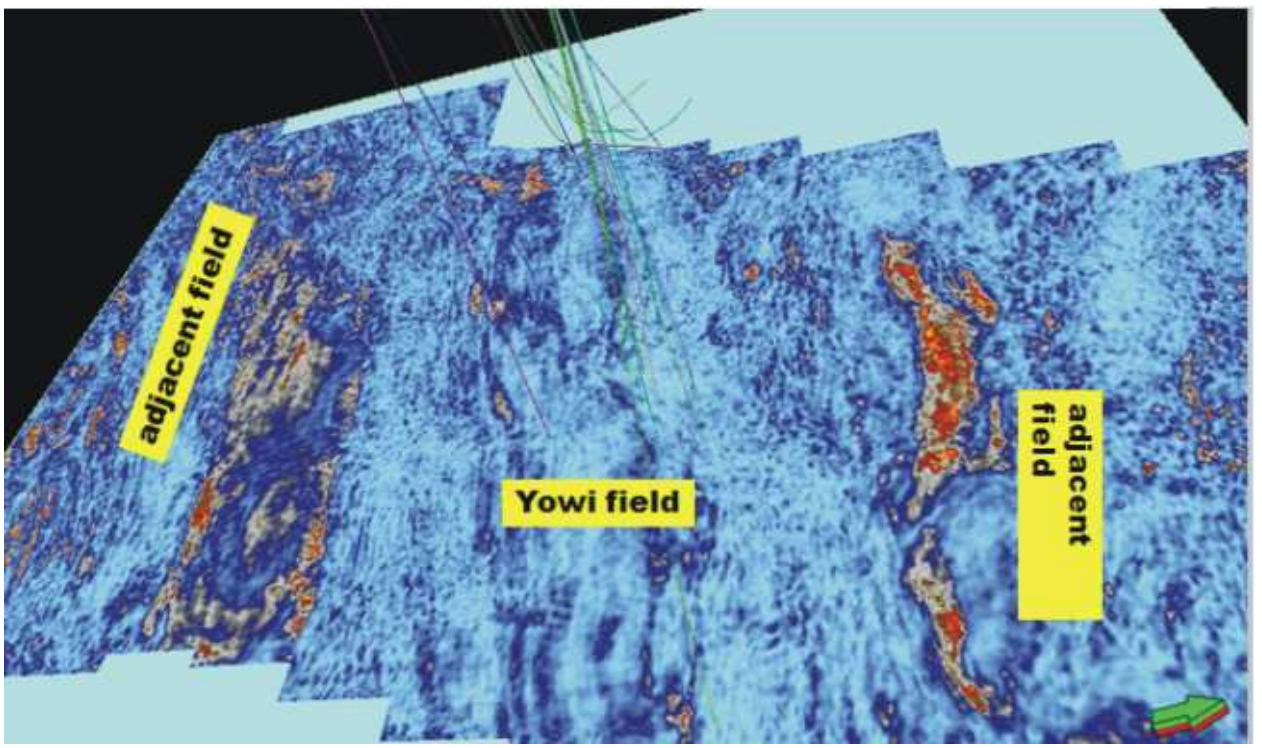

(b)

Fig. 10. (a) RMS Amplitude at time Slice $1410 \mathrm{~m} \mathrm{sec}$, (b) Time slice at $2207 \mathrm{~m}$ sec showing similar sand distribution pattern in adjacent areas (parallel to coastline) to Yowi Field 


\section{Chaotic and Channelized Architecture}

The chaotic facies is noticed from below $2400 \mathrm{~m}$ sec. This seismic facies pattern shows evidence of mass transport complex. They occur below $2200 \mathrm{~m}$ sec and represent deposits within deep marine Akata petroleum system (Fig. 11). The isolated high amplitude areas are sand-bodies suspected to be turbidite lobes and the meandering pattern should be a channel, which may be hydrocarbon bearing due to the high amplitude reflection (Fig. 12).

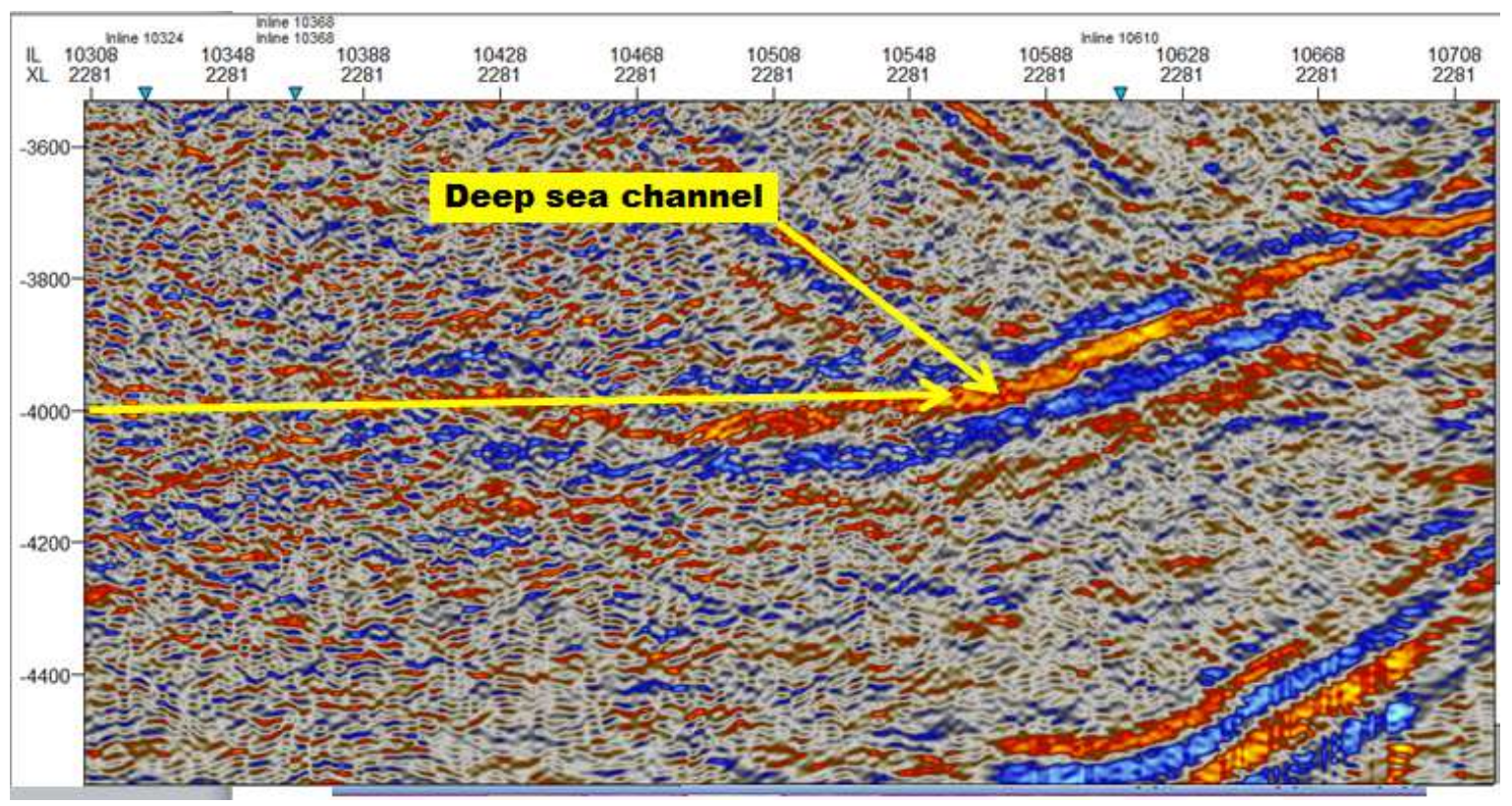

Fig. 11. RMS amplitude extraction for XLine 2281

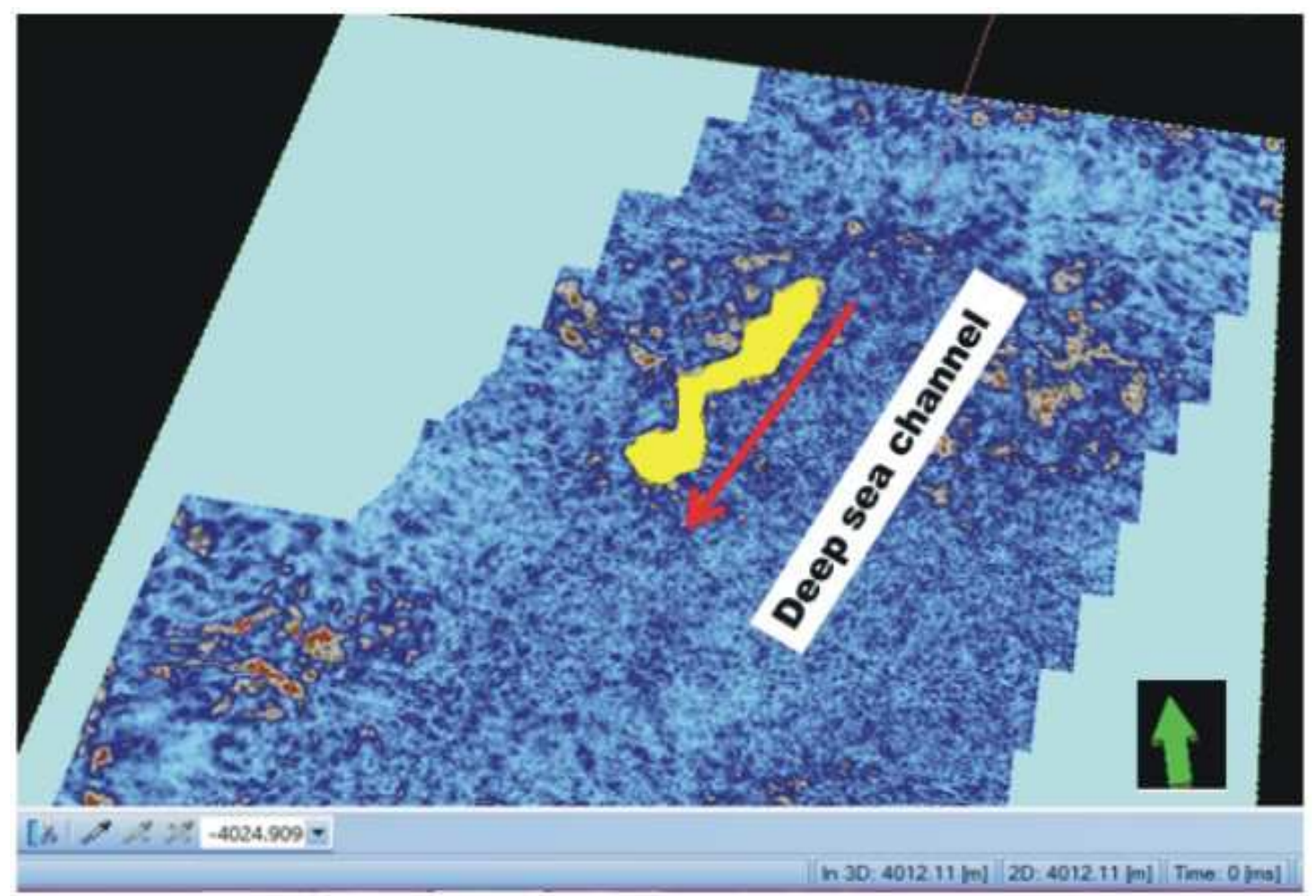

Fig. 12. RMS Amplitude at time slice $4024 \mathrm{~m} \mathrm{sec}$. High amplitude area shows a meandering channel of about $4000 \mathrm{~m}$ in length 


\section{Discussion}

\section{Petroleum Potential and Exploration Implications}

The geometry and architecture of geobodies in the study area showed configurations suitable for hydrocarbon accumulation. Generally, the Agbada section of the Yowi Field is made up of sediments deposited within the shoreface-shallow marine realm, composed of majorly stacked regressive barrier and shoreface complexes. Hydrocarbon is majorly confined to these deltaic-front sediments (Larue and Legarre, 2004; Jackson et al., 2005; 2009; Sech et al., 2009). This study documents the occurrence of thick stack regressive barrier and shoreface sands culminating in two structural highs on both the eastern and western flanks of the field as evident in reservoir N5.2 (Fig. 5b). They occurred within a depocenter on the south of a boundary fault located north of the field appropriate for structural traps and hydrocarbon occurrence. The growth fault creates lateral seal that will impede fluid communication between the adjacent depocenter thereby forming a faultsupported closure appropriate for hydrocarbon entrapment. Depth structure map of the N5.2 sand revealed that the greatest accumulation of sediments occurred towards the eastern flank of the field. High amplitude events in the lower section below 2000 milliseconds may signify reasonable prospects within the isolated sand bodies. Generally, sand bodies in the field demonstrate layer-cake architecture typical of shorefaceshallow marine setting. The geobodies are shore-parallel and extensive (Fig. 2, 8, 10b and 10b). The east and western parts of the field are separated by a distance of about $8 \mathrm{~km}$. The correlation panel showed wells on the east (well A2P2) and west (A9P2) with good continuity of facies (Fig. 2). Alternation of sand and shale is typical of paralic sequences (Agbada Formation) of deltaic sedimentation. This is the reason for huge hydrocarbon deposits that have been exploited for several decades in the basin. The reservoirs are massive and extensive with potentials for long production lifespan. The N5.2 sand has produced for more than one decade. The intervening shales are thick enough to serve as source rock and good seals. The western part of the field tends to be more marine or offshore-ward with thicker shales than the east having greater sand development (Fig. 2 and 3).

Wells were drilled in three locations in the field: Eastern, western flank and between the east and. Most wells were drilled into the N5.2 sand at about the same depths, except the two deepest test wells (A2P2 and A9P2). At shallower depth above the N5.2 sand ( $855 \mathrm{~m} \mathrm{sec}$, Fig. 8) all the wells penetrated the high amplitude event. The N5.2 sand falls between 1350 and 1400 milliseconds. Areas with highest Root-Mean-Square (RMS) amplitude values represent a porous and sand-prone facies; whereas sections characterized by low amplitude reflections may be interpreted as deposits resulting from pelagic or hemipelagic sedimentation, or a mud-rich and waterbearing facies. Some of the wells drilled into the N5.2 sand landed off the high amplitude events as revealed by RMS amplitude and Variance attributes (Fig. 13). This could lead to early water breakthrough with rapid decline in oil production, because, the low amplitude areas are more water-prone than hydrocarbon.

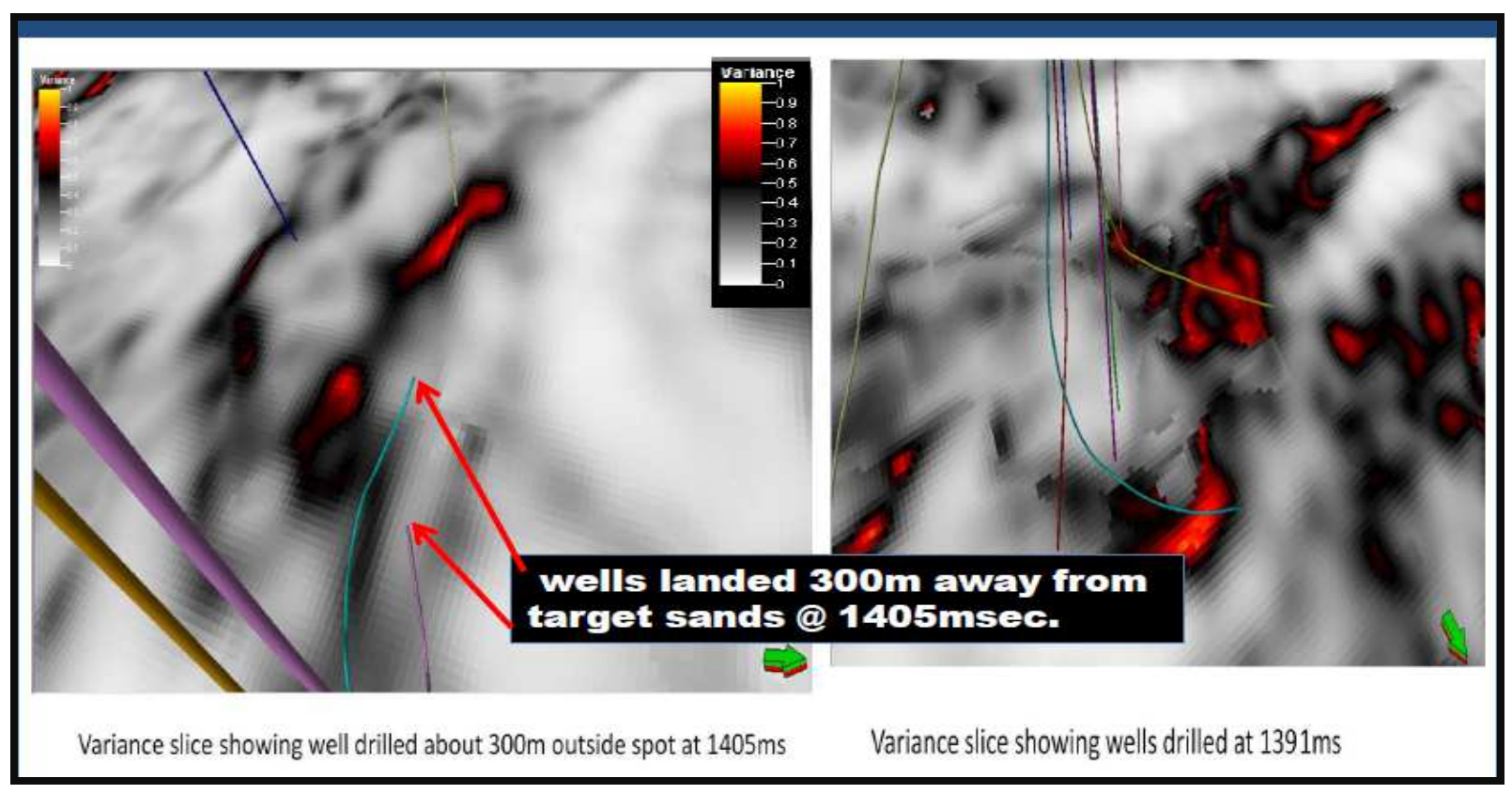

Fig. 13. Variance slice at 1405 and $1391 \mathrm{~m} \mathrm{sec}$ 


\section{Conclusion}

Well $\log$ and seismic volume attributes have established that shallow marine-shoreface sands are laterally extensive in the Yowi field and displayed layercake architecture. Using the RMS attribute the following depositional elements have been identified in the study area: Continental sand facies, beach/barrier/shoreface deposits, deep sea mass transport complex and channels. They reflect deposits resulting from two depositional processes which include fluvial and marine events. Seismic volume attributes are powerful tools that help the seismic interpretation process. They are useful in the identification of facies distribution patterns, architecture and geometry and sensitive to hydrocarbon presence. The consistent high RMS amplitude trends across the east and west of the field indicate the presence of a particular lithofacies (massive and laterally extensive sandstone body) occurring in the study area. These porous lithofacies are targets for hydrocarbon exploration in the field.

Most wells drilled into the N5.2 sand landed off high amplitude events. This may have contributed to significant coning and early rapid decline in oil production. The use of RMS amplitude and other volume attributes are reliable in geobody prediction and will serve as a guide in subsurface exploration.

\section{Acknowledgement}

The authors wish to acknowledge the O.B Lulu Briggs Chair in Petroleum Geoscience at the Institute of Petroleum Studies, University of Port Harcourt, Nigeria, for providing the platform for this research.

\section{Funding Information}

Funding for this research was generously supported by Engr. LeBari Nania and Mr. John Momta.

\section{Author's Contributions}

Prince Suka Momta: Undertook the PhD research from which this manuscript was developed and written.

Minapuye Isaac Odigi: Supervised the PhD work, read and revised the manuscript.

\section{Ethics}

This article is original and contains unpublished material. The corresponding author confirms that the second author read and approved the manuscript, and that there are no ethical issues.

\section{References}

Anstey, N. 2005. Attributes in color: The early years. Canadian Society Eyploration Geophysicists Recorder.
Bruso, J.M., S.L. Getz and R.L. Wallace, 2004. Gulf of guinea geology. Oil and Gas Journal's Special Report.

Burke, K., 1972. Longshore drift, submarine canyons and submarine fans in Development of Niger Delta. AAPG Bulletin, 56: 1975-1983.

Chopra, S. and K.J. Marfurt, 2005. Seismic attributes-a historical perspective. Geophysics, 70: 3SO-28SO. DOI: $10.1190 / 1.2098670$

Chopra, S. and K.J. Marfurt, 2007a. Seismic Attributes for Prospect Identification and Reservoir Characterization. 1st Edn., SEG Books, Tulsa, ISBN-10: 1560801417, pp: 464.

Chopra, S. and K. Marfurt, 2007b. Curvature attribute applications to 3D surface seismic data. University of Houston.

Chopra, S. and K.J. Marfurt, 2008a. Emerging and future trends in seismic attributes. Leading Edge, 27: 298-318. DOI: 10.1190/1.2896620.

Chopra, S. and K.J. Marfurt, 2008b. Seismic attributes for stratigraphic feature characterization. Society of Exploration Geophysicists.

Chopra, S. and K.J. Marfurt, 2009. Detecting stratigraphic features via cross-plotting of seismic discontinuity attributes and their volume visualization. University of Oklahoma.

Cook, G., A. Chawathé, D. Larue, H. Legarre and E. Ajayi, 1999. Incorporating sequence stratigraphy in reservoir simulation: An integrated study of the Meren E-01/MR-05 Sands in the Niger Delta. Society of Petroleum Engineers.

Durogbitan, A.A., 2014. Morphology of the Niger Delta: Local facies belts orientation versus depobelts and growth fault orientations. Proceedings of the NAPE Annual International Conference and Exhibitions, Nov. 9-13, Lagos, Nigeria.

Hart, B.S., R. Pearson, R. Pearson and G.C. Rawling, 2002. 3-D seismic horizon-based approaches to fracture-swarm sweet spot definition in tight-gas reservoirs. Leading Edge, 21: 28-35. DOI: $10.1190 / 1.1445844$

Howell, J.A. and S.S. Flint, 2005. Tectonic setting, Stratigraphy and Sedimentology of the Book Cliffs, the Parasequence of the Book Cliffs Succession, Sequences and Systems Tracts in the Book Cliffs, Sequence Stratigraphical Evolution of the Book Cliffs Succession. In: The Sedimentary Record of Sea-Level Change, Coe, A.L. (Ed.), Cambridge University Press, ISBN-10: 0521538424, pp: 135-208.

Husmo, T., G.P. Hamar, O. Høiland, J.P. Johannessen and A. Rømuld et al., 2003. Lower and Middle Jurassic. In: The Millennium Atlas: Petroleum Geology of the Central and Northern North Sea, Evans, D., C. Graham, A. Armour and P. Bathurst (Eds.), Geological Society, London, ISBN-10: 186239119X, pp: 129-156. 
Jackson, M.D., S. Yoshida, A.H. Muggeridge and H.D. Johnson, 2005. Three-dimensional reservoir characterization and flow simulation of heterolithic tidal sandstones. AAPG Bulletin, 89: 507-528. DOI: $10.1306 / 11230404036$

Jackson, M.D., G.J. Hampson and R.P. Sech, 2009. Three-dimensional modeling of a shoreface-shelf parasequence reservoir analog: Part 2. Geologic controls on fluid flow and hydrocarbon recovery. AAPG Bulletin, 93: 1183-1208. DOI: $10.1306 / 05110908145$

Larue, D.K. and H. Legarre, 2004. Flow units, connectivity and reservoir characterization in a wave-dominated deltaic reservoir: Meren reservoir, Nigeria. AAPG Bulletin, 88: 303-324. DOI: $10.1306 / 10100303043$.

Momta, P.S. and M.I. Odigi, 2015. Implications of sequence stratigraphic technique to petroleum exploration and production: A case study of XP field, Onshore Niger Delta, Nigeria. Int. J. Sci. Technol., 4: 235-247.

Orife, J.M. and A.A. Afbovbo, 1981. Stratigraphic and unconformity traps in Niger Delta: Abstract. AAPG Bulletin, 65: 251-265.

Petters, S.W., 1984. An ancient submarine canyon in the Oligocene-Miocene of the Western Niger Delta. Sedimentology, 31: 805-810. DOI: $10.1111 / \mathrm{j} .1365-3091.1984 . t b 00887 . x$
Reijers, T.J.A., 2011. Stratigraphy and sedimentology of the Niger Delta. Geologos, 17: 133-162. DOI: $10.2478 / \mathrm{v} 10118-011-0008-3$

Sech, R.P., M.D. Jackson and G.J. Hampson, 2009. Three-dimensional modeling of a shoreface-shelf parasequence reservoir analog: Part 1. Surface-based modeling to capture high-resolution facies architecture. AAPG Bulletin, 93: 1155-1181. DOI: $10.1306 / 05110908144$

Slatt, R.M., 2006. Stratigraphic Reservoir Characterization for Petroleum Geologists, Geophysicists and Engineers. 2nd Edn., Elsevier, Amsterdam, ISBN-10: 0080466818, pp: 492.

Sydow, J.C., J. Finneran and A.P.R. Bowman, 2003. Stacked Shelf-Edge Reservoirs of the Columbus Basin, Trinidad, West Indies. In: Shelf Margin Deltas and Linked Down Slope Petroleum Systems: Global Significance and Future Exploration Potential, Roberts, H.H., N.C. Rosen, R.H. Fillon and J.B. Anderson (Eds.), Adam's Mark Hotel, Houston, Texas, pp: 1.6.

Taner, M.T., 2001. Seismic attributes. Canadian Society Exploration Geophysicists Recorder, 26: 48-56. 